\title{
協調的判断に基づくバイオプロセスの異常診断・操作 システムの開発”。
}

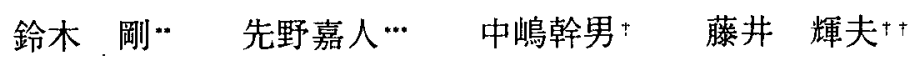 \\ 淺間 - - 佐藤一省 ${ }^{\dagger \dagger}$ 遠藤 熏 \\ Development of a Diagnosing and Operating System based on \\ Cooperative Decision Making for a Bio-process \\ Tsuyoshi SUZUKI, Yoshito SAKINO, Mikio NAKAJIMA, Teruo FUJIl, Hajime ASAMA, \\ Kazumi SATO and Isao ENDO
}

The paper describes a development of a diagnosing and operating system in which mutual cooperation between a system and an operator can be effectively used in decision making. Firstly, a concept of cooperation between the system and the operator was proposed. The authors discuss the cooperative method for plant operation and diagnosis. Then, the authors designed a framework of this system which is composed of three modules, namely a diagnosing module, an interface module and a supporting tool module. In this system, a knowledge base is represented by utilizing a fault tree and describing additional information for cooperative decision making. The authors implemented a prototype of the system for diagnosing human errors and malfunctions in a bioprocess system. Finally, the availability of the prototype system is shown through simulated system operation.

Key words: human interface, cooperation, human error, diagnosis, process system

\section{1. 緒言}

近年の製造プラント等に代表される複雑かつ大規模な人工シ ステムは, 計算機による自動化・高機能化により, 操作員がシ ステム状態を把握することを困難にしている.このようなシス テムのブラックボックス化が進むにつれ，操作員と人エシステ ムとの接点となるマン・マシン・インタフェースの重要性がま すます高まってきている.しかし, 従来のインタフェースの大 半を占めるユーザ主導型意思決定システムは, 人間の操作がシ ステムに直接反映するため，操作員の誤判断・啌操作などの ヒエーマンエラーがシスデム異常を引き起こしてしまう。一 方, 人間の誤判断を減らすために熟練者の思考過程をモデル化 したエキスパートシステムなどのシステム主導型意思決定シス テムは，与えられた知識以上のことは判断できないため対処で きる事態に限界がある.これらは, 人間・機械双方の欠点を表 している.

人間は,機械には不可能な優れた状態認識や柔軟な思考を行 えるが,それは常に完全ではなく，心身の状態や環境などに影 響を受けるという久点がある。一方，機械は，人間の苦手とす る複雑な演算や反復処理などには優れた能力を発揮するが, 情 報処理能力は限られており，柔軟性に欠ける。

ここで, 人間と機械との長所を活かし双方の短所を補うよう

- 原稿受付平成 11 年 10 月 4 日

“正会 貝 理化学研究所 (和光市広沢 2-1)

… 理化学研究所（当時東京理科大学所属. 現, 大阪府警察; 大 阪市中央区大手前 3-1-16)

† 理化学研究所 (現, 大阪大学工学部; 吹田市山田丘 2-1)

†† 理化学研究所 (現, 東京大学生産技術研究所; 港区六本木 722-1)

$\dagger^{\dagger \dagger}$ 東京理科大学大学院 (新宿区神楽坂 1-3)

$++^{+}+$理化学研究所 (和光市広沢 2-1)
な,すなわち,機能の相互補完を目的とした協調を実現するよ うなインタフェースが実現できれば,様々な状況に柔軟かつ適 応的に対処することが可能となると考えられる.

そこで本論文では，「人エシステムと人間との協調」を考虑 したマン・マシン・インタフェースについて議論する.ここで 述べる協調とは, 人工システムの不得意とする状態認識やそれ に基づく総合的な判断などは人間が行い，人間の不得意とする 複雑な演算や反復処理, 人間が犯してしまう誤操作などに関し てはシステムが支援し，適切な操作を行えるようにするなど， 人工システムの機能と人間の能力との融合を図ることである. 操作員とインタフェースとが協調的判断に基づき人工システム の異常診断と操作を行う意味からここでは，本システムを協 調的異常診断・操作システムと呼ぶ.

本論文では，操作員の経験が大きく影䭓する人工システムの 一例としてバイオプロセスを取り上げ，操作支援，および, 異 常診断を目的とした協調的異常診断·操作システムを設計し, そのプロトタイプを構築する. また, シミュレーションによ り，本システムの有効性を娭証する。

\section{2. バイオプロセスを対象とした協調的異常診断・操作 システム}

\section{1 バイオプロセスの操作支援と異常診断}

バイオプロセスは, 熟練者と初心者とで操作の信頼性が大き く異なる.これは,プロセスが内包する反応に比べ測定可能な 情報量が非常に少なく, 熟練者はプロセスの連転中に, 機械で は測定困難な情報を過去の経験や知識によって補いながら運転 制御をしているためと思われる。しかし，熟練者であっても誤 判断·䛊操作などをする場合があり,このようなとユーマンエ ラーはシステムの生産性に大きな影響を与える。 
従来より,ヒューマンエラーに関しては多くの解析がなされ ており，例えば, エラーのメカニズムを人問の情報処理の側面 から考察したものや, インタフェース設計のためのエラー分 析, 操作員の生理指標の測定による認知状態の解析など, 様々 な研究が行われてきた ${ }^{122}$. 一一方, システム運用時のエラーへ の対処に関しては，ファジィ・エキスパートシステムのよう な，熟練操作員の代替を果たすようなシステム344や，プラン 卜操作における協調的インタフェーズ)-81等も開発されてきた が,このようなインタフェースは, 主として機械が操作員の操 作を支援する方向での議論しかされておらず，人間の判断をシ ステムに反映させるような, 人間が機械を支援する方向も含め た相互協調的なアプローチは行われていない.

バイオプロセスでは,菌体内の化学的変化が生産の基本とな るため, 人間がシステムの内部状態を正しく予測し操作するこ とは非常に困難である.その一方で, システムがオンラインで 測定できる情報は限られており，例えば谙地の色やにおいと いった微妙な変化を伴う情報は測定不可能であるし，あるい は, 人間の経験を記述したり，心理状態を計測することは極め て困難である。また，操作時と同様に，システムの異常時に， その原因が操作員の誤操作なのかシステムの故障なのかを判断 するのも困難である. 特に, ヒューマンエラーの場合は, 操作 する人間の状態に要因が依存しているため, システムのみの診 断では認識できない.

協調的な判断支援や異常診断においては,このような情報を システムと人間とが協調 (対話) し適宜補： 合うことを可能に する。つまり,システムの操作や異常診断において, システム の情報と人間の知識や経験とを合わせることによって,システ ムの適切な操作や，従来では究明できなかった異常の要因を診 断することが可能となる.異常を引き起こした原因が人的要因 に起因するか物的要因に起因するかを認識できれば,エラーか らの回復やシステムのメンテナンスなども効率良く行うことが でき，さらに，究明された要因をその後の操作やインタフェー スの設計などにフィードバックすることによって,エラーへの 対応や防止策, システムの改善などを図ることが可能となると 考えられる。

\section{2 対象としたバイオプロセスの概要}

バイオプロセスでは,培養液中に含まれる微量な増殖制御因 子の量によってプロセスの挙動が大きく変化するため,プロセ スを安定に運転するには，原料を移入した際に、これらの増殖 制御因子の濃度を測定し，不足分を適宜添加することが必須で ある.このような增殖制御因子の濃度がプロセスに大きく影堷 した例として，ここでは，理化学研究所で保有する Rhodococcus属の一菌株の菌体增殖実験を取り上げた. 当研究 室で行ったこの菌体増殖実験によって，増殖制御因子として Rhodococcusの菌体增殖を促進する未同定のビタミンが酵母工 キス中に存在することが判明しており，この醰母エキスの添加 量によって菌体の増殖が大きく異なることが既に確認できてい る。つまり，このRhodococcusの菌体增殖は，酵母エキス添加 量をもって制御することが可能であり,最適な酵母エキス量を 添加すれば,初期の原料に対し希望の菌体增殖と最大の生産物 を得ることが可能となる。しかしながら，培盖液中に含有され るビタミシ濃度の測定は測定誤差が大きく，酵母エキスの添加 量の決定はプロセス操作者の経験に依存する.そのため，操作 者のミスやシステムの故障により醉母エキス添加量が最適な值 とならなかった場合には,生産物量が低下するという事態が発
生する.そこで,このRhodococcusの菌体増殖を効率良く行わ せるためには，操作者が培盖操作をする際の操作支援を行うと 共に，生産物量が低下した時には，その原因をヒューマンエ ラー, システムの故障のどちらの場合についても診断可能な協 調的異常診断・操作システムを構築する必要がある。

\section{3. 協調的異常診断・操作システムの設計}

操作員の操作支援およびシステムの異常診断を行うために, 本論文では図1のような構成のインタフェースの枠組みを設計 した. 本システムは, 診断部, 判断支援部, 表示部より構成さ れている.

診断部は，異常診断に必要な知識を搭載した知識べースと， その知識を利用して診断を行う推論機構とから構成されてい る.

診断部の知識ベースは, 異常事象と原因との因果関係を記述 し, 特に, 操作員との協調的判断を実現するために, 各事象が 「システムのみで自動的に判断可能」「操作員との協調的判断 が必要」といった協調的判断を行うのための情報を知識の中に 記述できるようにした。

推論機構は, 発生した異常事象から診断用の知識ベースを検 索し, 現在のデータで㟝断が進められなくなった場合,つま り，知識ベースに記述されている協調的判断のための情報を参 照し，協調的な判断が必要となった場合に，オペレータとの対 話的協調を経て診断を進め，原因を同定する。

判断支援部は，操作員の判断を支援するッールであり、シス テムを操作する際に操作貝の判断に必要な情報を提供する.こ の判断支援部によって，操作員は操作前にこれから行う操作方 法や操作量などを決定する際の参考とすることができる。

また, 操作員は, 表示部を通してシステムの操作や情報の入 出力を行う.

\section{4. バイオプロセスを対象とした協調的判断・操作 システムの試作}

本システムは, ワークステーション上に,エキスパートシス テム構築ツールであるGensym Corporation·G2リアルタイムエ キスパートシステムVersion 3.0 を使用して構築した。

\section{1 診断部の構築}

診断部の知識ベースは, 原因と結果の関係が記述しやすく操 作者に分かりやすいなどの理由から異常事象とその原因との因 果関係をツリ一構造によってて表現することとした.このッリー 構造を持った知識表現は,フォールト・ツリーのように単に各 事象間の因果関係のみを表すだけでなく,協調的判断を実現す るために，各ノードに「システムのみで自動的に判断可能」，

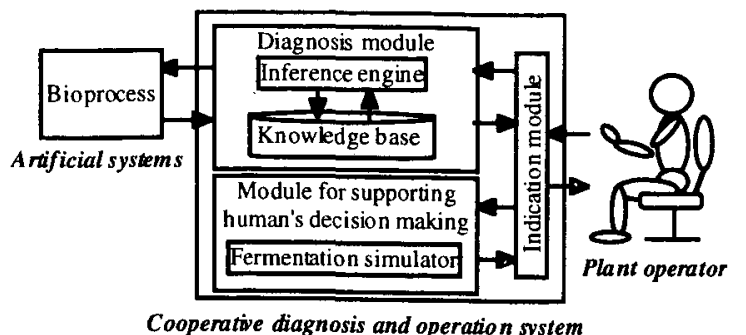

Fig.1 Scheme of a diagnosing and operating system based on cooperative decision making 
「操作員との協調的判断が必要」といった「協調的判断のため の情報」をッリーの各ノードの中に記述する。

この知識べースを作成するために，「生産物量の低下」を引 き起こす直接的な原因を実験熟練者からのヒアリングにより調 查した，その結果，「生産物量の低下」は，

1）ビタミン量が最適値よりも少ない,

2）ビタミン量が最適値よりも多い,

3）ビタミン量が最適値よりも非常に多い,

という3つの原因により生起することが確認された。ここれら は,ヒューマンエラーや培養槽の故障といった間接的な要因に より引き起こされる。ここでは，ヒューマンエラーの例とし て，操作手順のミス，入力ミス，䛊差の見積り間違い，計算ミ スなどを，また，培養槽の故障の例として，電気系統の故障や 装置の老朽化などによるバルブの故障や培養槽内の圧力異常な どを考虑している．この知識ベースのッリー表現の一部を図 2 に示す。この知識ベースでは，「生産物の消費」や「ビ夕ミ ン量が非常に多い」といったシステムの機能により計測が可能 な原因に関するノードは,システムのみで自動的に判断可能な ノードとして表されている。また，図中の太伜の「操作ミス」 や「入力ミス」,「操作手順のミス」といった, システム側が判 断できない原因に関するノードは，操作員との協調的判断が必 要なノードとして表されている。また，これら各事象はORの 関係で接続されており，同時には発生しない，G2上では，こ れらの知識を約 600 のルールと数值演算処理を行う約 200 の プロシージャとして構筑した.

推論機構は，異常を検出するとッリーの頂上事象であるノー ド「生産物量の低下」から知識ベースの縦型探索を開始する. システムのみで判断可能なノードでは必要なデー夕を自動的に 計測し，その事象が生起しているか否かの判断を行う。また， 例えば, 操作買の判断が必要なノードや「ビタミン量の入力ミ ス」のような操作員の誤操作にかかわる事象を表すノードに は, 操作員との協調的判断が必要という情報が記述されている ため，推論機構は，この情報を参照し操作員に質問を行うこと によって, 必要な情報の入力を促し，入力された情報に基づい て対応する事象が生起しているか否かの判断を行う。

\section{2 判断支援部}

バイオプロセスでは,あらかじめプロセスの挙動を予測して 操作量を決定する必要があるが, 操作員が複雑なプロセスの挙

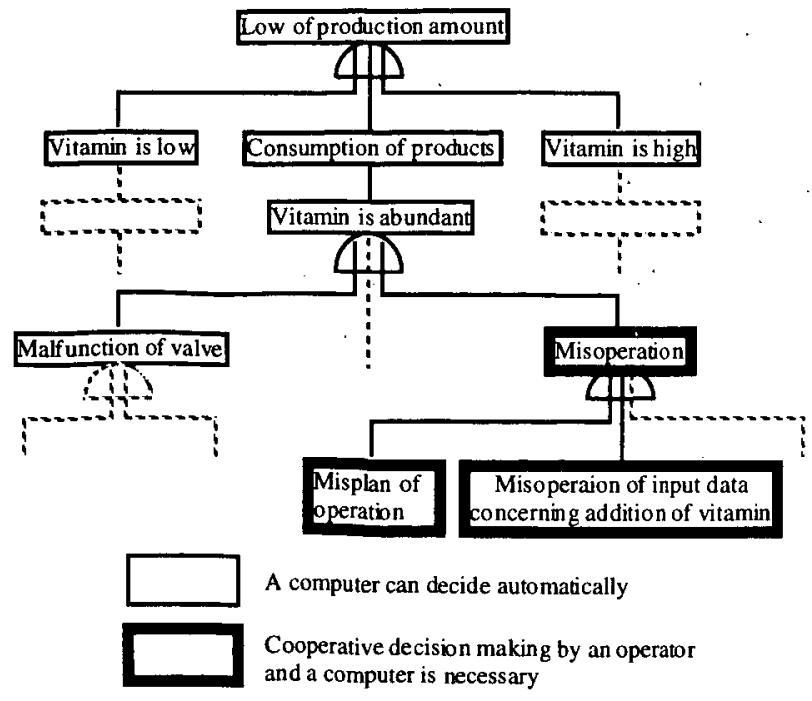

Fig.2 Subpart of a knowledge base

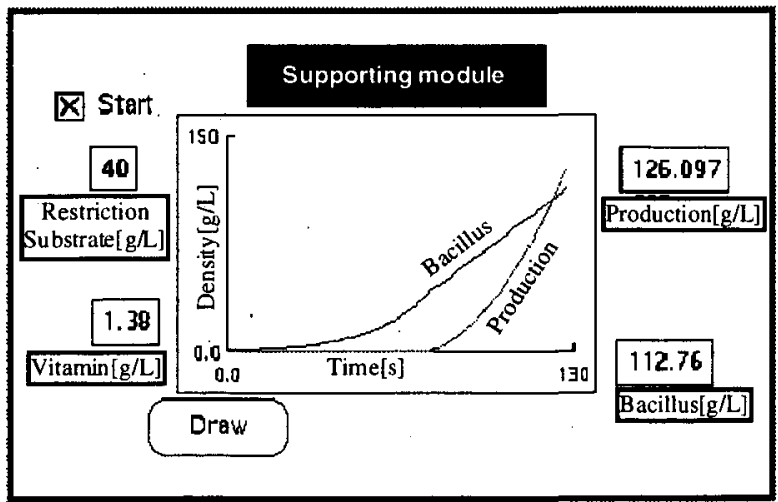

Fig.3 A subwindow of a fermentation simulation module for supporting human's decision making

動をいつも正しく予測することは難しい，そこで,ここでは判 断支援部として，操作量の決定に有用な培養プロセスのシミュ レータを構築した。この判断支援部は，

・内部に培養プロセスのダイナミクスが微分方程式を用いた モデル式として記述されており，これに基づいてシミュ レーションが行われる。

・操作量を数値で入力しスタートボタンをクリックすること でシミュレーションが行われ，その結果が数值およびグラ フで表示される.これにより，操作量に対する培養プロセ スの举動を予測することが可能である(図 3参照).

・評価する操作量を繰り返し入力できこれにより操作員は 試行錯誤的に最適操作量を推定することが可能である。

\section{3 表示部}

表示部は,主として操作具や表示器を通して情報の入出力を 行う環境を与える。操作員は，この表示部を介してシステムの 操作を行ったりデータを入手するため,表示器や操作具は操作 貝にとって使いやすいものでなければならない. 従って,プラ ントおよび操作システムからの情報を表示する表示器には, 視 認性の良さや，異常時に音などにより危険を操作員に知らせる などの機能が重要となる. 図4にプロトタイプシステムの表示 部の例を示す.

表示部には, 前述の判断支援部や知識ベース，また操作員に 培養結果やエラー原因などの情報を表示するメッセージボー ド,後述の仮想培養槽の操作パネルなどの各ウインドウが表示 される。操作パネルの表示は, 視認性を考虑してメー夕類の表 示を搪大できるようになっている. 知識べースは各ノードが色 分けされており，異常診断時には，操作員は各ノードの属性や 状態（生起しているか否か）を色によって判断でき, 診断の様 子を確認できる. また, 協調的判断が必要となる場合には, 操 作員に,Yes/No や数值の入力を促すためのウインドウが表示 される. 異常の発生や診断結果の表示については, ビープ音で 操作貝に知らせると共にメッセージボードにその内容を表示す る.

\section{5. 評 価 実 験}

\section{1 仮想培蒠槽の構築}

協調的判断・操作システムの試作にあたり，様々なヒューマ ンエラーや故障の状況を人為的に作り出すことが必要なため, ここでは，実際の培養槽を使用する代わりに培養槽の挙動を模 擬する「仮想培養慒」を計算機上に構等しこれを対象システ 
ムとして実験を行った. 仮想培養槽の構築にあたって考慮した ことは, 操作量に対する菌体の挙動, および培養中に起こるシ ステムの故障を模擬することである。

菌体の挙動については, 当研究室で行ったRhodococcusの菌 体増殖実験の結果を基に, 菌体量, 制限基質量, 生産物量, ビ タミン量などを考慮したモデルを作成した，また，システム故 障に関しては, 培養中のランダム時間に, 実験中に発生しやす い, 例えば醉母エキス供給バルブの故障などを考慮し, その影 響によって添加量が変化し菌体の挙動が変化するといった事象 などを取り上げた。

この仮想培養槽における操作量は酵母エキスの添加量であ り,原料に含まれている制限基質量に対して酵母エキス中に含 まれるビタミン量が最適になるように添加された時に, 最大の 生産物量が得られる.従って操作員のヒューマンエラーや培養 槽の故障などにより,ビタミン量が過大あるいは過小となった 場合に「生産物量の低下」という異常が発生する.なお, 仮想 培養槽においてオンラインで測定可能なデー夕は, 生産物量と 菌体量のみである.また, 操作員に表示されるデータについて は, 実際の培養槽で起こり得る計測誤差や外乱, 原料のばらつ きなどの計測困難な要因を模擬するために,乱数により誤差を 発生させることとした. 操作員は, 培養によって得られる生産 物を可能な限り大量に得るために, 培養に先だって原料のデー 夕 (制限基質量とビタミン量)を読み取り，これに基づいて， 操作量 (酵母エキス添加量) を決定し, 実際に添加するための 指令をシステムに与えることができる. また, 培養後に菌体量 および生産物量の計測結果を表示する. 図4は仮想培養槽の操 作パネルの表示である. 操作パネルは, 左側のメー夕に誤差を 含んだ制限基質量とビタミン量が表示され，それに基づき，操 作員はさらに添加するビタミンの量をスライダによって調節 し，スタートボタンによって培養を開始する，培養終了後に は, 培養結果がグラフおよび右側のメータに表示される。

\section{2 実験の概要}

構築したプロトタイプシステムの機能を確認し,その有効性 を評価するために、いくつかの稼働条件のもとで仮想培養槽を 操作し, 実験を行った。

培養を行う手順としては,まず操作員が仮想培養槽の培養前 のデー夕を読み取り，判断支援部を用いてシミュレーションを 行い,読み取ったデー夕を考慮しながら試行錯誤的に最適ビ夕 ミン量を推定し, 添加量を決定する. その後, ビタミン添加量 を仮想培養槽の入力用スライダを使って添加し, スタートボタ ンにより培養を開始する. 培養終了後, 生産物量が特定の量以

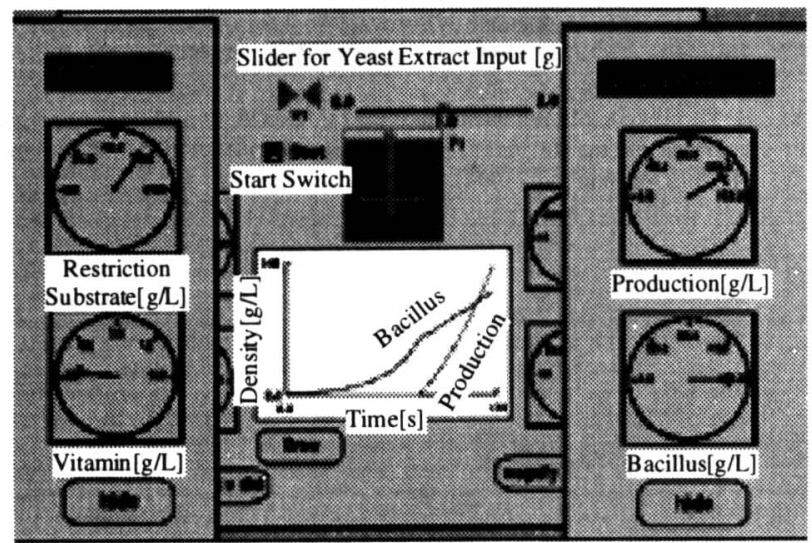

Fig. 4 Operation panel for a virtual fermentor
上得られたときには培養が成功したものとする。しかし，も し, 生産物量が特定の量より少ないときには, システムの故 障, あるいは, ヒューマンエラーなどの原因で「生産物量の低 下」という異常が発生していることとなり, 異常診断が行われ る. なお, 異常の原因となるエラーについては, 次の前提条件 を設けた。

a）知識ベースに搭載されていないエラーは起こら ない

b) 一度に複数のエラーは起こらない

c）協調的判断時には操作員はエラーを起こさない

\section{3 実験結果および考察}

図5は, 実験結果の一例であり, ヒューマンエラーが原因で 培養が失敗した場合の表示画面を示している. 操作員は, 判断 支援部を用い醉母エキスの最適添加量を $1.04 \mathrm{~g} / \mathrm{L}$ と推定し添 加した後, 仮想培養槽のスタートボタンを押し培養を行った。 その結果, 異常診断部は「生産物量の低下」を検出し, 原因の 探索を開始した. 原因の探索過程で,ビタミン量が過剩である ことが判明し, 操作員の操作ミスの可能性があるため, 協調的 判断が必要なノードに達したとき, システムは, 画面中央に操 作員に対し質問を行うウインドウを表示した.ここでは, 実際 にどのくらいの酵母エキスを添加したかったのかを質問した. これに対し, 人間が $1.04 \mathrm{~g} / \mathrm{L}$ を入力すると, 添加量が間違っ ているというメッセージを表示した. 実際に操作員がここで添

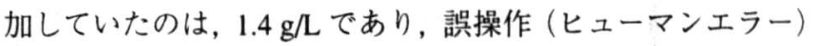
の結果, ビタミン量が過剩になり生産物の低下が起こったこと が判明した。また, 診断部により検知された異常と究明された 原因が，それぞれ MESSAGE BOARDを介して提示された。

また,システム側の故障が起こった場合も同様に原因の究明 が可能であった. 操作員が判断支援部を用いて添加量を決定し た後, 酵母エキスを添加し培養を行った結果, 異常診断部は 「生産物量の低下」を検出し, 異常原因の診断を開始した。診 断過程で, ビタミン量が少ないことが判明し, システム側が考 えられる原因を表示し,電気系統のシステムの状況などをさら に詳しく操作員に質問し総合的判断を仰いだ結果, 酵母エキス 供給バルブの故障を検出することが可能であった.

培養が成功した場合には，培養が成功したことを示すメッ セージが提示されることを確認した.

以上の実験より,

1) 判断支援部を用いた最適操作量の決定

2）プロセスの異常の検出および機械による情報の提示 という, 機械から人間への操作支援と,

3）操作員による情報の入力

4）操作員による総合的判断

という, 人間から機械への判断支援の四つの機能相互補完的な 協調が確認でき, プラントの操作, およびヒューマンエラーや 人工システム側の故障に起因する異常の診断が有効に行えるこ とが確認できた。

今後の課題として,この実験では, 主に本システムの基本機 能について実証するために, いくつか前提をおいたが, 柔軟か つ適応的なシステムを構築するためには、これらの基本機能を さらに拡張しなければならない.例えば, 協調判断時に操作員 が誤入力をした場合や, 同時多発的に異常が発生した場合の対 処, 知識ベースにはない原因により新たな異常が発生した場合 などにおける操作員とシステムの協調的な対処が考えられる。 また，表示部に対しては，さらに人間工学的·認知工学的な見 地からの画面構成や協調時の対話性の向上などの改良を行うこ 


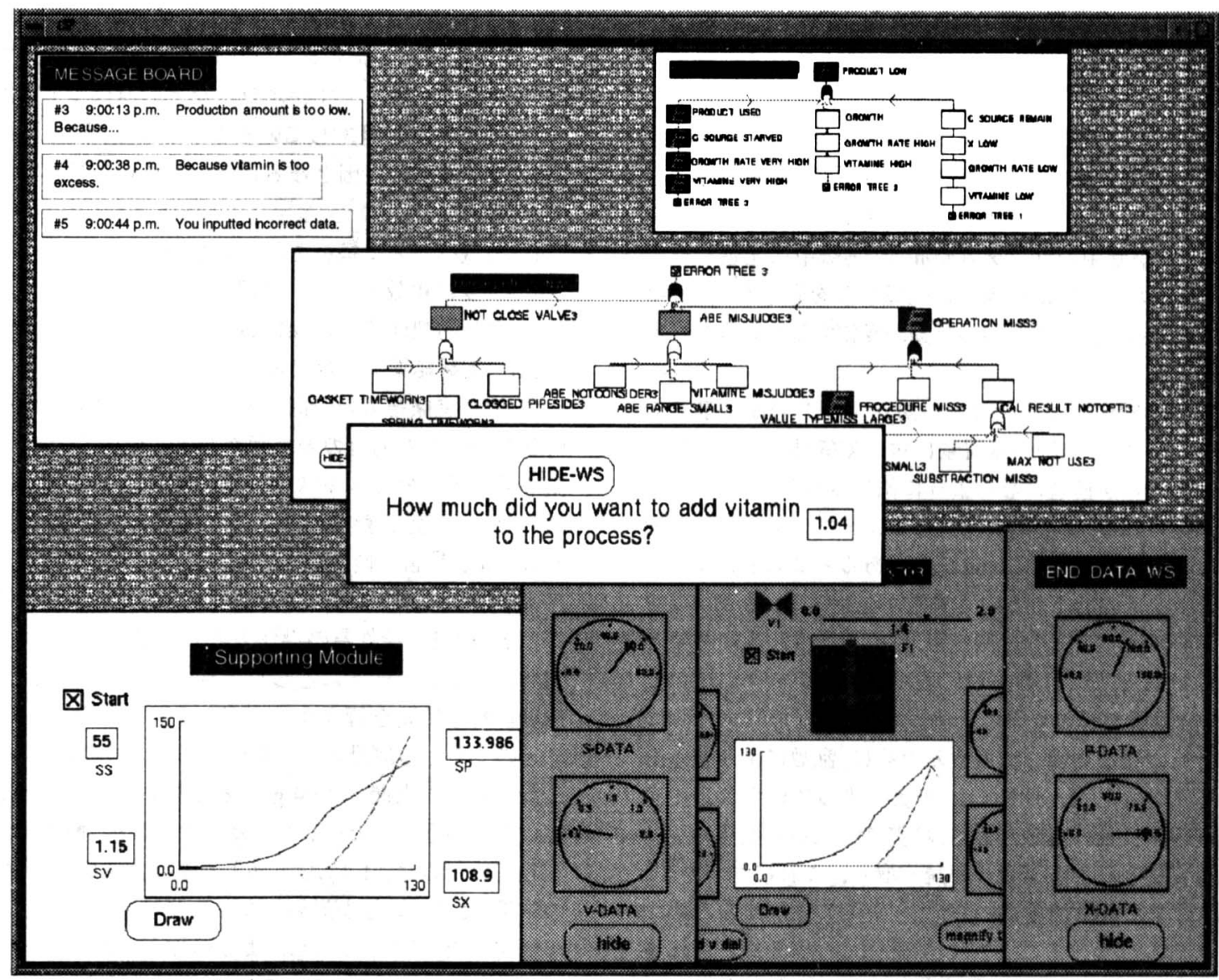

Fig.5 Example of a human error for cooperative decision-making and operation

とが好ましい.

\section{6. 結言}

本論文では, 人エシステムの操作ループに積極的に操作員を 含めることにより，操作員と人エシステムの操作システムが協 調しながらお互いの欠点を補い,より高度な機能を実現するた めの協調的判断に基づく異常診断·操作システムの枠組みを提 案した. そのプロトタイプシステムとして, 自動化が困難であ り, かつ, 操作員の経験的な判断が必要とされるバイオプロセ スを対象とした協調的異常診断・操作システムを構符した.ま た，評価実験を行うことにより，プラントの操作，および， ヒューマンエラーや人工システム側の故障に起因する異常の診 断が有効に行えることを示した.

本研究で提案した協調的異常診断・操作システムの枠組み は, 人エシステムの操作における操作員の役割を重視してお ク, また, 様々な人エシステムに適用可能なため, 人間一機械 系を実現する汎用的枠組みとなり得る.

なお, 本研究は, 科学技術庁の平成 6 年度科学技術振興調 整費による「システムと人間の協調のための人間特性に関する
基礎的·基盤的研究」の一環として, 理化学研究所で実施した 「人工システムと熟練操作員の協調的判断 · 操作機構の研究」 の成果の一部をまとめたものである.

\section{参 考 文 献}

1) 林 喜男：人間信頼性工学一人間エラーの防止技術一，海文堂出 版 (1984).

2) 谷村富男：ヒューマンエラーの分析と防止，日科技連出版社 (1995).

3) C. von Numers, M. Nakajima, T. Siimes, H. Asama, P. Linko and I. Endo: A Knowledge Based System Using Fuzzy Inference for Supervisory Control of Bioprocesses, J. Biotechnol. 34 (1994) 109.

4) T. Siimes and P. Linko: Real-Time Fuzzy-Knowledge-Based Control of Baker's Yeast Production, Biotechnol. and Bioeng., 45 (1995) 135.

5) 中村孝太郎, 小林 重信：並列対話方式に基づく故障診断システ 么, 人工知能学会誌, 4, 1 (1989) 52 .

6) J. J. Lisboa: Nuclear Power Plant Availability and the Role of Human Factors Performance, IEEE Trans. Nucl. Sci., 37, 2 (1990)980.

7) C. R. Hardy, S. M. Randall: A Software Tool for Incorporating Operator Response into Nuclear Plant Accident Analysis, IEEE Trans. Nucl. Sci., 4, 4 (1994) 1394.

8) H. Yoshikawa. M. Takahashi and T. Arai: Concept on Mutual Adaptive Interface and the Related Experimental Study, 1994 Japan-U.S.A. Sym. Flexible Automation, (1994) 503. 